\title{
The Problems and Measures of the Government Network Spokesman System Existing in the New Media Age
}

\author{
Jiang $\mathrm{Ke}$ \\ School of Public Management \\ Yunnan University of Finance and Economics \\ Kunming, P.R. China \\ $1341824069 @ \mathrm{qq} . c 0 m$
}

\begin{abstract}
Information disclosure is not only the necessity of developing information society, but also guarantees citizens' right to know and the requirement of construction of democracy. With the high speed development of Internet and information technology, Internet access to information, the important way of expressing interests, network events have been attracting the attention of people. In view of the new media era in the spread of Internet public opinion is not enough, government spokesman as the breakthrough point, based on the network is put forward to perfect the system construction, strengthening training, such as transparent as the main content of the countermeasures and suggestions, in order to explore the network popularization order media challenge for our government news office.
\end{abstract}

Keywords $\longrightarrow$ new media; government news spokesman; system

\section{INTRODUCTION}

With the advent of the era of network, information technology, the rapid update, represented by the Internet of the widespread application of new media is gradually changing the traditional mode of public opinion propagation mode, under the traditional media's audience is totally in a passive position, and under the age of network audience is information users and manufacturers, unidirectional has been broken under the traditional way of public opinion, the past relying on passive delayed release pattern already can't adapt to the new environment of current network times public opinion transmission, the complexity of the network, information content, network image amplification characteristics, has made the spread of public opinion present magnified, clear, interactive and complication, etc. And the government network spokesman is built in such a special environment. [1]

The government network spokesman is a government official communication with users via Internet official channel, is a wide range of soliciting comments on the Internet, and net users doubts in the shortest possible time reply, and will be announced the government's position, principles and policies on the Internet with net users love interactive platform. Not only shows that the government and to the attention of the media cooperation, but also the government for the public's right to know, the right to express the respect such as democratic rights. Network media popularization order new environment brings the new challenges to our government news office. Network news spokesman and traditional media news spokesman system construction is also facing a new test.

\section{NEW MEDIA}

\section{A. The Definition of New Media}

Concept of new media is in 1967 by the CBS television network (CBS) technology institute, gold mark (p. Gold mark) was the first to put forward. New media is compared with the traditional media, under the condition of current technology, is based on digital technology and Internet technology, mobile communication technology on media forms. Its morphological diversity, according to the development of Chinese new media report at the Chinese academy of social sciences (2010), mainly includes news sites, network BBS communities, blogs, social networks, network real-time communication, new media, video, mobile news, mobile TV, China's IPTV and digital TV, digital newspapers, electronic, etc.

At present, the global Internet users have more than 2 billion, not including more than 5 billion mobile phone users. China Internet network information center (CNNIC) in Beijing released 33 times the China Internet network development state statistical report showed up to the end of December 2013, 618 million Internet users in China, the Internet penetration rate of $45.8 \%$. Among them, 500 million mobile Internet users, the annual growth rate of $19.1 \%$, continue to maintain the leading terminal position online. Internet users in the use of mobile Internet population proportion to $81.0 \%$ from $74.5 \%$ at the end of 2012, far higher than other equipment the proportion of Internet users on the Internet. [2]

\section{B. The Characteristics of the New Media}

The information spread fast, can be instant and allows real-time characteristics of the new media content into the sea of 24 hours of continuous rolling updates, continually scrolling news content updates, the network can be events live, especially in emergencies, network is more than a newspaper editor time is short, more rapidly, the public can see at any time in the network of the development of events per minute.

- Huge amounts of information 
Internet information can say everything, openness of time and space led to the mass storage of information, can be horizontal to hold information from all over the world. Network media space open led to the spread of geographic global coverage, network information can be shared globally.

- $\quad$ Strong interactivity

The various information transmission nodes media users (such as Internet, mobile phone users) can be two-way, multidirectional information communication between each other.

\section{- Community}

Network transmission is not only a comprehensive, initiative, participatory, permeability and operational characteristics, but also has the characteristics of flexibility, openness and interactivity. People mostly in the form of "social" on the net, all kinds of community, and free BBS, chat rooms, etc in the corners of the virtual. [3]

\section{UNDER THE BACKGROUND OF NEW MEDIA THE GOVERNMENT NETWORK SPOKESMAN SYSTEM}

\section{A. The Connotation of the Network, A Spokesman for the System}

Network spokesman system is government departments to make public opinion adequately express, actively respond to the network, correctly guide network public opinion supervision, and promote information disclosure, to carry out the public informed and expression power, set up good government image and establish a network administrative system, its core is through the network system, a spokesman for the release of timely and accurate administrative information demands, and respond to Internet users among the general public and the government set up a new channel policy and public opinion interaction, correctly guide the network public opinion, build good public opinion environment. [4]

\section{B. The Government Network Spokesman Background and Development}

All media era and the globalization of information medium of the new environment bring new challenges to the government's news office. Emergency happens, the rapid development of network public opinion. Some local governments and departments, and change the past "seal", the practice of "wall", "cut", using the Internet to contact Internet public opinion "zero distance", "network news", a spokesman for the new role arises at the historic moment. [5]

On this base, the government leaders at all levels and functions, head of the department have opened the box on the net, provided convenience for people to reflect the livelihood of the people through the network, it shall be regarded as the prototype of network news. Two sessions in 2009, a CPPCC member for Yunnan "hide-and-seek" event proposals, recommendations, a spokesman for the government to set up the network news, online timely reply, guarantee the network information channels, in the same year in July, Yunnan provincial party committee propaganda department put forward the building of the government departments at all levels ", a spokesman for the network system ". Yunnan, Guizhou, Guangdong, Jiangsu and other provinces and cities have preliminarily formed network asked administration, network news spokesman, Wei Bo and other forms of online government news release, the new pattern of information communication and public opinion guidance.

\section{The Significance of Network Spokesman}

Network spokesman can be summarized as the significance of using the five elements of the spread of the network media will integrate; As the medium of the Internet for news spokesman assembled mass audience, also greatly expanded the content of the news release; Combined with the advantages of the timeliness, interactivity, makes the spread of network news spokesman can achieve ideal effect, to a certain extent, make up for the deficiency of the traditional news spokesman system. [6]

[4] Set up network spokesman for the government to guide network public opinion correctly.

Network real-name post way, a spokesman for the timely release of authoritative information early intervention, to defuse rumors spread misinformation and authoritative information, to a considerable extent to guide public opinion to the benign development, to create the largest controllable and calm on the solution of the event.

- A spokesman for the implementation of network system is the important way to make government

Network era government image matters, network spokesman system has changed the traditional way of information transfer, reduce the distance of the government and the public. Concluded government-ordinary people communication make full use of network platform, interactive new relationship, in the traditional face-to-face communication and other forms of the government and the public has added a new way, this new approach will improve the efficiency of government departments to deal with information, thus to cultivate government officials diligent and honest, efficient and pragmatic work style, to promote effective play to the functions of the government, create good government image.

- To implement network spokesman system is conducive to the construction of a harmonious government-ordinary people relations.

The establishment of the network, a spokesman for the system, which is beneficial to further open channels of contact with the masses of the people's government, safeguards the people's fundamental interests, won the endorsement and support of the masses of the people; to consolidate the ruling foundation, government-ordinary people relation, build a service-oriented government.

"Fully respect the Internet users and the network public opinion, is the government should fulfill the responsibility of the network news spokesman. The government need to treat correctly network news spokesman, analysis, and guide the network public opinion, in a timely manner to users reflect the problem put forward opinions shall be suitable for reply, do it 
with net users reciprocity, can fully protect the public has a right to know and to supervise".

\section{The Main Body of Characteristics of the Network Spokesman}

Government network spokesman, as network transmission of the main body, has the characteristics of three aspects. First of all, it is a government television networks. The governments through the network channels better go deep among the masses, understand, collect intelligence and improve decision making. Second, network asked administration to undertake. Network spokesman don't stay in the role of "setter", through the improvement of the corresponding support mechanism, become one of the government network "clerk" and "intimate clerk" of Internet users. Finally, it is the image of the mold. Not every individual citizens will express online assessment for the work of the government, which tend to have a lot of "looking", some online hot spot and focus on the formation of public opinion seems public response. Thus, in the process of network transmission image cognition, need for information of all kinds of different nature, actively participate in and guide to build online public opinion, set up, maintain and repair the public cognition about the government's image.

\section{The Existing Problems of The NeTwork SpoKesman}

In the process of development, network news spokesman system level and artificial factors, also in the development of more or less has some problems and the insufficiency, embodied in the following aspects:

\section{A. Lack of Legal Protection, Supervision and Accountability Mechanism Is Not Sound}

At present, our country has not clear legal and administrative rules and a regulation relating to the press spokesman system is discussed, and as a rising star of the government network spokesman system is more lack of legislative guarantee. This will inevitably affect the establishment of the network news spokesman system, improve and promote.

On the one hand, the network news, a spokesman for the speech, transfer information, through the network represents the agency's position. But once appear; saying the wrong thing cause problems, due to the lack of legal protection, spokesman for their own rights might be harmed. Network news spokesman system, on the other hand, due to lack of scope of information disclosure, disclosure procedures, responsible to carry out the aspects such as the lack of clear rules, as well as the supervision and accountability mechanism is not sound, will lead to network news spokesman system become a mere formality, useless. Thus, influence the information timeliness, authenticity, normality; reduce the public trust of government.

\section{B. Expound the Fact Unknown}

In addition to system level, also has its own factors, a spokesman for the. Part of the network news spokesman in response to an Internet problem, the formation of some tough questions, often deliberately concealing the truth, or cover it with a hidden way, put don't open hands. Network spokesman cannot show, to increase the administrative accountability and transparency. Speech must be true, otherwise it will cause bigger storm, for example: "hide and seek", "fishing enforcement", dung "and" horse "and a series of public events, the public wants to get information from government demands increase, more formed the strong tide of public opinion to promote the development of events.

\section{The Information Feedback in Time}

At present, the network news, a spokesman for the main response to comments slowly for some hot spots and net users reflect problems, often appear position is not active, or don't reply in a timely manner, in continues to follow up and reply due efficiency. Some network news spokesman in response to comments, often use "read", "I don't have time to shoot the breeze with you" and other words respond to Internet users. Behind the nature, the comparison of the surface, shuffle, over time, Internet users on network news spokesman sincerity will doubt, a spokesman for the credibility will decline.

\section{Equal Communication Was Not Enough}

Part of the network news, not enough respect for the opinions of Internet users, Internet users, a spokesman for idea "ranking is still there. One is speaking gesture commanding, sincere enough. Part of the network, a spokesman for reply net users' comments, and its way of speaking is very difficult for users to accept, mandarin, too much rhetoric and completely put Internet users in a pure audience's position, let users have a commanding lead lectured, without attention listen to the opinions of Internet users. Second, interaction is insufficient, some network news spokesman in response to comments, just pure "said," without sincerity, equality are discussed, with net users didn't express their real opinions on the events, with net users did not form a fully interactive.

\section{NETWORK NEWS SPOKESMAN SYSTEM IMPROVEMENT MEASURES}

In the face of the complex network environment, network news spokesman, compared with the traditional news spokesman in psychological compressive ability, information screening ability, communication ability, professional ability, etc., has a higher request. In the face of complex network of public opinion, emergency, how to establish communication with the public rationality, a spokesman for the channel, how to undertake the mission of their own, can be improved from the following several aspects.

\section{A. Spokesmen for the Need to Further Enhance Communication, Information Screening Ability and Keen Thinking}

A qualified network news spokesman, need with the aid of network the transmission platform, convey to the public the most real and clear information and ideas. Spokesman in the process of communication with the public, to groveling, not to pose as "official", each with equal dialogue attitude towards the public, in line with the attitude of serious and responsible to answer every question. After mastering a large number of 
first-hand information, it can extract distinctive sharp point of view, and made his speech is logical and persuasive.

\section{B. Quality Ability Remains to Be Further Improved of the Network Spokesman}

As the representative of the government network spokesman, must first work of department have fully familiar with the knowledge and state policies and regulations, adhere to the correct political ideas and value orientation. At the same time, in the face of the complexity of the network environment, open, variability, Spokesman should not only actively cultivate journalism, social science, political science, psychology, professional quality, but also a wide field of vision and broad mind, in public communication, every single word or phrase are required to pay attention to scientific, rational, embodied humanistic care, enhance the sense of responsibility, and strive to achieve "and" special "unity".

\section{Strengthen the Training of Network Spokesman}

Network news spokesman, who are also "spokesman", in addition to master basic network control ability, news literacy, firm political position, strong political sensitivity is essential diathesis for do a good job. Many network news spokesman also exist "didn't want to say" "dare not say" no ", is, of course, many reasons, but mainly with the network, a spokesman for their own media literacy and political literacy.

Network news spokesman in addition to grow in experience in practice, another important channel is consciously training network news spokesman. Cannot wait until one of network news spokesman exercise "mature" in practice, should be in the "scientific theory knowledge and the combination of ideological and moral education", "according to their aptitude", "the combination of theory and practice of" "combining the professional knowledge and comprehensive knowledge" principle, the relevant departments to have taken to the or is on the network news, a spokesman for the positions of cadres to formatting training in political quality and professional quality.

\section{Perfect the Institutional Construction of Network News Spokesman}

Given the strong role in the field of network in information dissemination and public opinion, network news spokesman system not only an expedient measure, and should make the institutionalization, in the aspect of system construction adhere to the principle of specialization, open and internationalization. At the same time, some problems in the aspects of network news release system, must also implement the accountability system, shall be investigated for the responsibility of the relevant person in charge. Only in this way, the network news spokesman system can better play its role, and effectively implement on for a long time.

\section{THE CONCLUSION}

Network news is under the background of new media, a spokesman for a new way of government public relations, Internet users in the first place of speech as an improved work force. Of course, to make the government network spokesman platform really become a bridge between the government and the public, in addition to establish its credibility and improve its working efficiency, also depends on the vast number of Internet users enhance media literacy, rational ask government information. We believe that, with the deepening of the practice, the government network spokesman in building a service-oriented, open government, contributed to the government scientific decision-making, promote socialist democratic politics construction will play a positive role.

\section{REFERENCES}

[1] Ling Yu. The government network spokesman system effectiveness research [D]. Yunnan University of finance and economics, 2011.

[2] The China Internet network information center (CNNIC). 33 times China Internet network development state statistic report [Z]. 2014(1).

[3] Why government "a spokesman "from the reality to the network[OL].http://news.xinhuannet.com/focus/content_12010515.htm, 2009-09-10.

[4] Ling Yu, Xie Jinlin. Try to talk about the role of the government network spokesman, combined with the government network spokesman and the similarities and differences between traditional government spokesman $[\mathrm{J}]$. Journal of central south forestry university of science and technology (social science edition), 2011 (2).

[5] Luan Ying. Under the background of new media the government network spokesman system, new pr [J]. Journal of Internet age. 2010 (7).

[6] http://baike.baidu.com/view/2713538.htm? Fr = Aladdin.

[7] The text should be in two $8.45 \mathrm{~cm}(3.33 ")$ columns with a $.83 \mathrm{~cm}(.33 ")$ gutter. 